Article

\title{
An Empirical Test of Capital Structure Theories for the Vietnamese Listed Firms
}

\author{
Hoang Huy Nguyen ${ }^{1}$, Chi Minh Ho ${ }^{2}$ and Duc Hong Vo ${ }^{2, *(D)}$ \\ 1 Vietnam-The Netherlands Economics Program, Ho Chi Minh City 7000, Vietnam \\ 2 Business and Economics Research Group, Ho Chi Minh City Open University, \\ Ho Chi Minh City 7000, Vietnam \\ * Correspondence: duc.vhong@ou.edu.vn
}

Received: 12 April 2019; Accepted: 2 August 2019; Published: 10 September 2019

\begin{abstract}
Raising capital efficiently for the operations is considered a fundamental decision for any firms. Since the 1960s, various theories on capital structure have been developed. Various empirical studies had also been conducted to examine the appropriateness of these theories in different markets. Unfortunately, evidence is mixed. In the context of Vietnam, a rising powerful economy in the Asia Pacific region, this important issue has been largely ignored. This paper is conducted to provide additional evidence on this important issue. In addition, different factors affecting the capital structure decisions from the Vietnamese listed firms are examined. The Generalized Method of Moment approach is employed on the sample of 227 listed firms in Ho Chi Minh City stock exchange over the period from 2008 to 2017. Findings from this study suggest that the Vietnamese listed firms follow the trade-off theory to determine their capital structure (i.e., to determine the optimal debt level). In contrast, no evidence has been found to confirm that the pecking order theory can explain the financing decisions of the Vietnamese listed firms, as previously expected. In addition, findings from this study also indicate that 'Fund flow deficit' and 'Change in sales' are the most two important factors that affect the amount of debt issued for the Vietnamese listed firms. Implications for academics, practitioners, and the Vietnamese government have also been emerged from the findings of this paper.
\end{abstract}

Keywords: pecking order theory; trade off theory; capital structure; GMM; Vietnam

\section{Introduction}

Capital always plays a crucial role in all firm activities. As such, raising capital efficiently for the operational activities is considered a fundamental decision for any firms. Since the 1960s, various theories and empirical researches have been conducted to examine the impacts of the capital structure decisions on firm's value. Among the number of capital structure theories, three notable theories are highly recognized including: (i) the pecking order theory; (ii) the trade-off theory; and (iii) the market timing theory. An intensive literature review indicates that both trade-off and pecking order theories have always been playing a dominate role in firms' financing decisions. However, debates have also emerged whether which theory that best explains for capital structure decisions of firms. The trade-off theory indicates that profitable firms have a tendency to increase debt to utilize the benefits from tax shields. In contrast, the pecking order theory argues that profitable firms prioritize internal funds first in order to reduce their debt or firms will use external funds when retained earnings are inadequate. Market-timing theory also receives supports, albeit limited, from empirical studies that managers tend to issue new stocks in the good timing of the market. Agha et al. (2013) considered that all three theories exhibit their own weaknesses. In the case of the trade-off theory, even though the theory extensively explains the decision for a capital structure, it ignores an important fact that 
debt is negatively correlated with profitability. The pecking order theory on the other hand provides a straightforward explanation for this relationship. However, mixed evidence has also emerged.

Shyam-Sunder and Myers (1999) and Yu and Aquino (2009) suggested that the pecking order theory can explain better for capital structure decisions from firms. Shyam-Sunder and Myers (1999) considered that the pecking order model is more robust than the target adjustment model although the model, once independently tested, appears to perform well. Yu and Aquino (2009) found that the pecking order theory better explains financing behavior of the Philippine listed firms than the trade-off theory.

In contrast to the arguments from Shyam-Sunder and Myers (1999) and Yu and Aquino (2009), Frank and Goyal (2003), and Razak and Rosli (2014) considered that the trade-off theory can better explain the capital structure decisions of firms than the pecking order theory. Frank and Goyal (2003) found that internal financing is insufficient to cover investment expenditures on average. A much stronger relationship between net equity issued and financing deficit is observed than net debt issuance and financing deficit. Razak and Rosli (2014) emphasized that the trade-off theory showed a stronger explanation on financing decisions of selected firms than the pecking order theory.

In practice, private enterprises frequently confront with the problems of capital structure and issued debt. In Vietnam, during the period of 2010-2015, after the global financial crisis in 2008 and the world depression in 2012, deposit interest rate was around 6-8\%, while lending interest rate, which firms can issue from banks, was more than $10 \%$, on average. Due to these global economic issues, the tightening monetary policy from the State Bank of Vietnam (SVB) gave pressure on domestic production. It was hard for firms to issue formal debt in order to foster their production, although private enterprises, especially small and medium enterprises account for a large proportion of Vietnamese GDP (approximately $43 \%$ in 2010 and $43.2 \%$ in 2015).

Since 2014 after the two recent global crisis, SVB changed its direction to loosening policy, in which SBV lowered and stabilized the lending interest rate around 7-8\%. Later on, in 2018, Decree number 168 from the Vietnamese Government on the problem of private bond loosed its previous regulation in order to encourage firms to raise their financial funds and diversify their capital structure. In previous Decree (Decree number 90 activated in 2011), firm can only issue private bond if it had positive profit in the previous year. That requirement was removed from the current activated Decree (Decree number 168). Even that, in 2018, total private bond issued from Vietnamese private corporations was approximately $7 \%$ of GDP. That was a relatively low rate compared to the average level of the region (21\%). These efforts from the Vietnamese Government and SVB seemed to weakly affect to the capital structure of private firms.

Due to the mixed evidence from previous studies, in particular for the case of an emerging market such as Vietnam, this paper is conducted to examine the importance of the capital structure theories in the context of Vietnam and to consider an appropriate model for Vietnamese listed firms to consider when conducting financing decisions. In addition, the paper also considers different factors which have also greatly contributed to the financing decisions of Vietnamese listed firms.

In order to obtain the above objectives, the paper utilizes various models on the ground of previous studies from Shyam-Sunder and Myers (1999), and Frank and Goyal (2003), Yu and Aquino (2009), and Razak and Rosli (2014). The pecking order theory is tested using two distinct models including the (original) pecking order model and the partially aggregated pecking order model. In addition, the trade-off theory is tested using the target adjustment model. In addition, the study uses the effect of factors on leverage model to measure the impact of different factors on capital structure decisions from the Vietnamese listed firms. The paper employs a Generalized Method of Moment (GMM) approach on the ground of a panel dataset of 227 firms from all sectors listed in Ho Chi Minh City stock exchange (HOSE) over the period from 2008 to 2017. The data set excludes listed firms from finance, insurance, and investment sectors. 
The paper is structured as follows. Following this introduction, Section 2 reviews relevant literature. Then, Section 3 describes the research methodology utilized in this paper. Data and empirical results are presented in Section 4, followed concluding remarks in Section 5.

\section{Literature Review}

Corporate capital structure has been widely considered in empirical studies with the focus on the determinants of financing decisions. Various aspects have been studied including the effect of corporate governance (Giroud and Mueller 2010, 2011; Morellec et al. 2012; Wen et al. 2002) or the influence of managerial characteristics (Berger et al. 1997; Coles and Li 2018; Friend and Lang 1988). Findings from these studies indicated that corporate capital structure is mostly affected by firm's characteristics. However, it is noted that none of these studies investigated the appropriateness of the theories on firms' financing decision to explain the corporate capital structure.

To test for the appropriateness and the validity of the theoretical models on financing decision, a number of papers have been conducted. The pecking order theory was validated to explain firm's financing decisions in studies by Shyam-Sunder and Myers (1999), Vijayakumar (2011), Atiyet (2012), Sheikh et al. (2012), Pacheco (2016), Balios et al. (2016), Maças Nunes and Serrasqueiro (2017), Trinh et al. (2017). Razak and Rosli (2014) supported the extended pecking order model whereas Yu and Aquino (2009) argued that the trade-off theory was more appropriate than the pecking order theory in explaining firms' financing decisions. However, Chirinko and Singha (2000) criticized the validity of the tests adopted in Shyam-Sunder and Myers (1999). This paper presents and discusses selected papers on this important research issue in order to identify and highlight the research gap in the context of an emerging market such as Vietnam.

To test traditional capital structure models against the pecking order model, Shyam-Sunder and Myers (1999) used a dataset of 157 US firms over the period from 1971 to 1989. The study started with the year-end values of the book debt ratio of each firm in 1971. Then, the book debt ratios of the later years were generated by ascertaining the funds flow deficit which is calculated by real investment, dividends, operating cash flow and others. The firm is supposed to retire debt in the case of negative deficit, and issue debt in the case of positive deficit. The key empirical results are briefly described as follows: (i) the pecking order model best describes firm's financing behavior; (ii) the adjustment target model, once independently tested, appeared to perform well; (iii) when the two models were jointly tested, the significance of the estimated coefficients from the pecking order model did not vary whereas the performance of the target adjustment model reduced even though the estimated coefficients from the model were still statistically significant; and (iv) firms not only intended to use debt to finance the need of cash in the short term but also in the case when the deficits were unexpected. These findings demonstrate the robustness of the pecking order model in explaining firms' behavior to capital structure decisions.

Yu and Aquino (2009) tested the validity of the pecking order model and the trade-off model to explain a financing behavior of the Philippine listed firms over the period 1990 to 2001. Findings from this study supported for the pecking order model due to the negative relationship between profitability and leverage, while the annual change in total liabilities is mostly explained by financing deficit. Yu and Aquino (2009) used the model of Shyam-Sunder and Myers (1999) and added dummy variable for years 1992-2001 to control time fixed effects when the pecking order model was tested. The results showed that firms followed the trade-off model in selecting capital structure model.

Chirinko and Singha (2000) indicated that the empirical evidence of Shyam-Sunder and Myers (1999) did not evaluate both the pecking order and static trade-off models. Chirinko and Singha considered the plausibility of three alternative external financing patterns and raised a question in relation to the validity of Shyam-Sunder and Myers (1999) conclusions. Chirinko and Singha (2000) argued that using the model of Shyam-Sunder and Myers (1999) provided difficulties in evaluating the validity of the pecking order model. As a result, they suggested that it is essential to have alternative tests to identify capital structure determinants and to distinguish one from other hypotheses. 
Frank and Goyal (2003) employed a dataset of the American public trading firms from the 1971 to 1998 period to test the validity of the pecking order theory. Two different approaches were applied in the paper. The first approach is that the fund flow deficit was utilized in order to account for the net debt issued. The second approach is that leverage was used. Frank and Goyal (2003) concluded that internal financing is insufficient to cover investment expenditures on average. This conclusion is in contrast to what is usually suggested. External financing is considerably used.

Razak and Rosli (2014) examined various theories of the capital structure and tested the static trade-off theory and the pecking order theory. The study used data from 200 listed firms in Malaysia over the period 2007 to 2012. Three models were tested including the pecking order model, the extended pecking order model, and the static trade-off model, to explain financing decision of firms in relation to new debt issuance. Findings from this study presented that the issuance of new shares was not affected by internal fund deficits. As such, the pecking order hypothesis expecting firms to issue debt to finance internal fund deficit was statistically rejected. However, findings from the extended pecking order model presented another story. The hypothesis supporting a positive relationship between financial activities and issuance of new debt is statistically accepted. Razak and Rosli (2014) continuously conducted further regression analysis to test the hypothesis of the extended pecking order model. The results indicated that new debt issuance was positively influenced by a long-term debt repayment and capital expenditure.

Kopecky et al. (2018) provided an alternative equilibrating process which markedly differs from the Modigliani (Modigliani and Miller 1958) and Miller (Miller 1977) theorem in terms of the prediction of debt uses, to achieve the same optimal level for firm values. This alternative process reinstitutes the prospect of capital structure irrelevancy. The study indicates that the takeover market can alter the stock market valuations such that firms may find it optimal not to recapitalize, even though predictions of the standard discounted cash flow model with recapitalization costs suggested that they have to recapitalize.

\section{Methodology}

This paper utilizes four different models on the ground of various studies of Shyam-Sunder and Myers (1999), Frank and Goyal (2003), Yu and Aquino (2009), and Razak and Rosli (2014) in the context of Vietnam. The pecking order theory is tested by two models including the original pecking order model and the partially aggregated pecking order model. In addition, the trade-off theory is tested using the target adjustment model. Together with these analyses, the paper also uses the effect of factors on leverage model to examine the impact of different factors on capital structure decisions from the Vietnamese listed firms. This study uses the panel Generalized Method of Moment (GMM) estimation to test the robustness of the pecking order theory as well as the trade-off theory and to measure the impact of different factors on capital structure decisions of the Vietnamese listed firms. Flannery and Rangan (2006) and Nunkoo and Boateng (2010) observed that recent studies in developed countries have a tendency to use the GMM estimation technique to conduct empirical analyses on the capital structure issues. In addition, Kannadhasan et al. (2018) emphasized that the GMM consistently estimates the dynamic model and deals with the endogenous problems by employing efficient instrumental variable (IV) techniques.

The pecking order model is tested on the ground of the model of Shyam-Sunder and Myers (1999) which has been widely used in previous studies including Frank and Goyal (2003), Yu and Aquino (2009), and Razak and Rosli (2014). The model can be expressed as below:

$$
\Delta D_{i t}=\alpha+b_{P O} D E F_{i t}+e_{i t}
$$


where $\Delta D_{i t}$ represents the amount of debt issued or retired by firm $i$ in year $i . b_{P O}$ is the pecking order coefficient and $e_{i t}$ is the error term. $D E F_{i t}$ is the fund flow deficit of firm $i$ in year $i$ and is calculated using the following equation:

$$
D E F_{i t}=D I V_{i t}+C F I_{i t}+\Delta N W C_{i t}-C F O_{i t}
$$

where $D I V_{i t}, C F I_{i t}, \triangle N W C_{i t}$, and $C F O_{i t}$ are dividend payments, net investment, change in net working capital, operating cash flows for firm $i$ in year $i$ respectively.

The partially aggregated pecking order model was based on Frank and Goyal (2003) which proposed to use the fund flow deficit $(D E F)$ equation to estimate the amount of debt issued or retired $(\Delta D)$.

$$
\Delta D_{i t}=a+b_{D I V} D I V_{i t}+b_{C F I} C F I_{i t}+b_{N W C} \Delta N W C_{i t}-b_{C F O} C F O_{i t}+e_{i t}
$$

where $\Delta D_{i t}$ represents the amount of debt issued or retired by firm $i$ in year $t$. $C F O_{i t}$ is the operating cash flows of firm $i$ in year $t$. DIV $V_{i t}$ represents dividend payments of firm $i$ in year $t$. CFI is the investing cash flow of firm $i$ in year $t . \Delta N W C_{i t}$ represents the change in net working capital of firm $i$ in year $t . e_{i t}$ is the error term.

The target adjustment model on the ground of Shyam-Sunder and Myers (1999) study was used to test the validity of the trade-off theory.

$$
\Delta D_{i t}=\alpha+b_{T A} \Delta D_{i t}^{*}+e_{i t}
$$

where $\Delta D_{i t}$ is the amount of debt issued or retired by firm $i$ in year $t$. $D_{i t}^{*}$ represents the target debt level for firm $i$ in year $t$ calculated by multiplied the historical mean of the debt ratio for each firm with total capital. $b_{T A}$ is the target-adjustment coefficient and $e_{i t}$ is the error term.

Frank and Goyal (2003) used other factors to account for firm's leverage. The leverage regression was developed utilizing five factors: profitability $(P)$, log sales $(L S)$, market-to-book ratio $(M T B)$, tangibility of assets $(T)$, and fund flow deficit $(D E F)$.

As such, the effect of factors on leverage model specification is as follows:

$$
\Delta D_{i t}=a+b_{T} \Delta T_{i t}+b_{M T B} \Delta M T B_{i t}+b_{L S} \Delta L S_{i t}+b_{P} \Delta P_{i t}+b_{D E F} D E F_{i t}+e_{i t}
$$

where $\Delta D_{i t}$ represents the amount of debt issued or retired by firm $i$ in year $t . \Delta T_{i}$ is Change in assets of firm $i$ in year $t . \Delta P_{i t}$ represents the change in profitability of firm $i$ in year $t . \Delta L S_{i t}$ is the change in log sales of firm $i$ in year $t . \triangle M T B_{i t}$ is the change in market-to-book ratio of firm $i$ in year $t$. $D E F_{i t}$ represents fund flow deficit of firm $i$ in year $t$.

\section{Data and Results}

Data were collected from financial reports, and annual reports of listed firms operating in all sectors in Ho Chi Minh Stock Exchange (HOSE) over the period 2008 to 2017 except for firms operating in finance, insurance, and investment sectors. Firms with missing or incomplete data were excluded from the analysis. The remaining data forms a balanced panel dataset. Table 1 presents the outcome of descriptive statistics for all variables used in this study. All variables have 2268 observations, except change in log sales $(\Delta L S)$ which has 2267 observations. 
Table 1. Descriptive Statistics.

\begin{tabular}{cccccc}
\hline Variable & Obs. & Mean & Std. Dev. & Min & Max \\
\hline$\Delta D$ & 2268 & 0.1424 & 1.5380 & $(59.1252)$ & 10.6219 \\
$D E F$ & 2268 & $(0.2350)$ & 1.6005 & $(13.7638)$ & 61.6392 \\
$D I V$ & 2268 & $(0.0588)$ & 0.0736 & $(1.2161)$ & 0.0730 \\
$C F I$ & 2268 & $(0.0892)$ & 1.4522 & $(3.3698)$ & 66.0117 \\
$\Delta N W C$ & 2268 & 0.0192 & 0.8129 & $(17.6784)$ & 16.3728 \\
$C F O$ & 2268 & 0.1063 & 0.5968 & $(7.4473)$ & 12.7931 \\
$\Delta D^{*}$ & 2268 & 0.1102 & 1.4033 & $(41.2042)$ & 9.3302 \\
$\Delta T$ & 2268 & $(0.0095)$ & 3.0170 & $(101.0872)$ & 101.8906 \\
$\Delta M T B$ & 2268 & 0.0627 & 1.1848 & $(20.7629)$ & 20.8969 \\
$\Delta L S$ & 2267 & 0.1038 & 0.5555 & $(4.2825)$ & 12.6414 \\
$\Delta P$ & 2268 & $(0.0359)$ & 2.1643 & $(63.4109)$ & 53.3619 \\
\hline
\end{tabular}

Notes: $\triangle D_{i t}$ : the amount of debt issued; $D E F_{i t}$ : Fund flow deficit; $D I V_{i t}$ : Dividend payments; CFI: Investing cash flow; $\triangle N W C_{i t}$ : Change in net working capital; $C F O_{i t}$ : Operating cash flows; $\Delta D_{i t}^{*}$ is the target debt ratio; $\Delta T_{i}$ : Change in assets; $\Delta M T B_{i t}$ : Change in market-to-book ratio; $\Delta L S_{i t}$ : Change in log sales; $\Delta P_{i t}$ : Change in profitability.

This study employed the panel Generalized Method of Moment (GMM) estimation to test the validity of the models and to measure the impact of different factors on capital structure decisions from Vietnamese listed firms. Table 2 shows the results for different estimations for the pecking order model.

Table 2. Estimation results of the pecking order model.

\begin{tabular}{lc}
\hline Explanatory Variable & $\begin{array}{c}\text { Dependent Variable } \\
\text { Amount of Debt Issued }(\boldsymbol{\Delta D})\end{array}$ \\
\hline Fund Flow Deficit $(D E F)$ & $-0.572^{* * *}$ \\
& $(0.029)$ \\
\hline Constant & $82.09 * * *$ \\
& $(14.750)$ \\
\hline Number of observations & 2268 \\
Number of firms & 227 \\
\hline Notes: Standard deviations in parenthesis. ${ }^{* * *}$ Significant at 0.01 level.
\end{tabular}

The hypothesis of the pecking order model is that the amount of debt issued has a positive relationship with the fund flow deficit $\left(b_{P O}>0\right)$ indicating that firms prefer to issue debt to finance the fund flow deficit. However, the regression coefficient of the model is negative $\left(b_{P O}=-0.572\right)$ and statistically significant at the level of one percent $(p<0.01)$. This indicates that the results do not support the pecking order theory in the context of the Vietnamese market. In a nut shell, Vietnamese listed firms do not prefer to issue debt to finance the fund flow deficit.

Table 3 describes Arellano-Bond test for first-order autocorrelation AR(1) and second-order autocorrelation $\operatorname{AR}(2)$ in the first-differenced errors which are conducted to verify the consistent degree and robustness of the empirical results. The estimated values confirm that second order autocorrelation is not in existence.

Table 3. Arellano-Bond Test for the pecking order model.

\begin{tabular}{lcc}
\hline \multirow{2}{*}{ Arellano-Bond } & \multicolumn{2}{c}{ System GMM } \\
\cline { 2 - 3 } & Z-Value & $\operatorname{Pr}>\boldsymbol{z}$ \\
\hline First-order autocorrelation AR(1) & -3.61 & 0.000 \\
Second-order autocorrelation AR(2) & -1.44 & 0.149 \\
\hline
\end{tabular}

Table 4 presents the results obtained for different estimations of the Partially Aggregated Pecking Order Model. 
Table 4. Estimation results of the partially aggregated pecking order model.

\begin{tabular}{lc}
\hline \multicolumn{1}{c}{ Explanatory Variables } & $\begin{array}{c}\text { Dependent Variable } \\
\text { Amount of Debt Issued }(\boldsymbol{\Delta D})\end{array}$ \\
\hline Dividend Payments $(D I V)$ & $-0.821^{*}$ \\
\hline Investing Cash Flow $(C F I)$ & $(0.423)$ \\
\hline Change in Net Working Capital $(\Delta N W C)$ & $-1.117^{* * *}$ \\
& $(0.052)$ \\
\hline Operating Cash Flow $(C F O)$ & 0.030 \\
& $(0.125)$ \\
\hline Constant & $-1.272 * * *$ \\
& $(0.166)$ \\
\hline Number of observations & 16.720 \\
\hline Number of firms & $(16.240)$ \\
\hline Notes: Standard deviations in parenthesis. ${ }^{*}$ Significant at 0.1 level, ${ }^{* * *}$ Significant at 0.01 level.
\end{tabular}

The regression coefficient of dividend payments $(D I V)$ is negative $(-0.82)$ and statistically significant at the level of 10 percent. The result is consistent with the findings of Vo and Nguyen (2014) and Tran and Vo (2015) who reported a negative relationship between dividend and firm leverage. The regression coefficient of operating cash flows (CFO) and investing cash flow (CFI) are also negative and significant at the level of one percent. Operating cash flow and investing cash flow have negative relationships with the amount of debt issued $(\Delta D)$ while there is no impact of the net working capital $(\triangle N W C)$ on the amount of debt issued $(\Delta D)$.

The hypothesis of the partially aggregated pecking order model is that the amount of debt issued or retired is positively related to dividend payments (DIV), investing cash flow (CFI) and change in net working capital $(\triangle N W C)$ but is negatively related to operating cash flows of firm (CFO). However, the empirical results do not support the hypothesis of the partially aggregated pecking order model.

Table 5 describes Arellano-Bond test for first-order autocorrelation AR(1) and second-order autocorrelation $\mathrm{AR}(2)$ in the first-differenced errors are conducted to verify the consistent degree and robustness of the model results. The testing values confirm that second order autocorrelation is absent.

Table 5. Arellano-Bond test for the partially aggregated pecking order model.

\begin{tabular}{lcc}
\hline \multirow{2}{*}{ Arellano-Bond } & \multicolumn{2}{c}{ System GMM } \\
\cline { 2 - 3 } & Z-Value & $\operatorname{Pr}>\boldsymbol{z}$ \\
\hline First-order autocorrelation AR(1) & -4.45 & 0.000 \\
Second-order autocorrelation AR(2) & -0.60 & 0.549 \\
\hline
\end{tabular}

Tables 6 and 7 present estimation's results and validation test of the target adjustment model (Shyam-Sunder and Myers 1999). Table 8 reports the results attained for different estimations of the effect of factors on leverage model using the system GMM. 
Table 6. Estimation Results of the Target Adjustment Model.

\begin{tabular}{lcc}
\hline \multirow{2}{*}{ Explanatory Variable } & Fixed Effects & Random Effects \\
\cline { 2 - 3 } & \multicolumn{2}{c}{ Dependent Variable } \\
& \multicolumn{1}{c}{ Amount of Debt Issued $(\Delta \boldsymbol{D})$} \\
\hline Target Debt Ratio $\left(\Delta D^{*}\right)$ & $0.714^{* * *}$ & $0.739^{* * *}$ \\
& $(0.018)$ & $(0.017)$ \\
\hline Constant & $0.137^{*}$ & $0.131^{*}$ \\
& $(0.075)$ & $(0.075)$ \\
\hline Number of observations & 2268 & 2268 \\
\hline Number of firms & 227 & 227 \\
\hline
\end{tabular}

Notes: Standard deviations in parenthesis. ${ }^{*}$ is significant at 0.1 level, ${ }^{* * *}$ is significant at 0.01 level.

Table 7. Statistics Test of the Target Adjustment Model.

\begin{tabular}{lcc}
\hline \multirow{2}{*}{ Statistics Tests } & \multicolumn{2}{c}{ System GMM } \\
\cline { 2 - 3 } & Chi-Square & Pr $>$ Chi-Square \\
\hline Hausman & 9.78 & 0.1342 \\
Breusch-Pagan Lagrange multiplier (LM) & 152.76 & 0.0000 \\
\hline
\end{tabular}

Table 8. Estimation results of the effect of factors on leverage model.

\begin{tabular}{|c|c|}
\hline Explanatory Variables & $\begin{array}{c}\text { Dependent Variable } \\
\text { Amount of Debt Issued }(\Delta D)\end{array}$ \\
\hline Fund Flow Deficit (DEF) & $\begin{array}{c}-0.530 * * * \\
(0.057)\end{array}$ \\
\hline Change in Log Sales $(\Delta L S)$ & $\begin{array}{l}0.512 * * * \\
(0.177)\end{array}$ \\
\hline Change in Market to Book Ratio $(\triangle M T B)$ & $\begin{array}{l}(0.040) \\
(0.097)\end{array}$ \\
\hline Change in Profitability $(\Delta P)$ & $\begin{array}{l}(0.023) \\
(0.036)\end{array}$ \\
\hline Change in Tangibility $(\Delta T)$ & $\begin{array}{c}0.080 \\
(0.071)\end{array}$ \\
\hline Constant & $\begin{array}{l}51.74 * * \\
(22.200)\end{array}$ \\
\hline Number of observations & 2267 \\
\hline Number of firms & 227 \\
\hline
\end{tabular}

Notes: Standard deviations in parenthesis. ${ }^{* *}$ is significant at 0.05 level, ${ }^{* * *}$ is significant at 0.01 level.

The regression coefficient of fund flow deficit $(D E F)$ is negative $\left(b_{D E F}=-0.530\right)$ and statistically significant at the level of one percent $(p<0.01)$. Change in log of sales $(\Delta L S)$ has a positive relationship with amount of debt issued (0.178) and is statistically significant at the level of one percent.

We consider that the above findings are consistent with our observations of the economic environment in Vietnam. Lending interest rate in Vietnam has been maintained at the average level of around 7.8 percent per year for the last five years. This stability of interest rate in Vietnam encourages Vietnamese firms to absorb more debt in order to take the advantage of the financial leverage. Findings from this paper reconfirm this position and observation. Figure 1 below illustrates the lending interest rate in Vietnam from 2008 to 2017. 


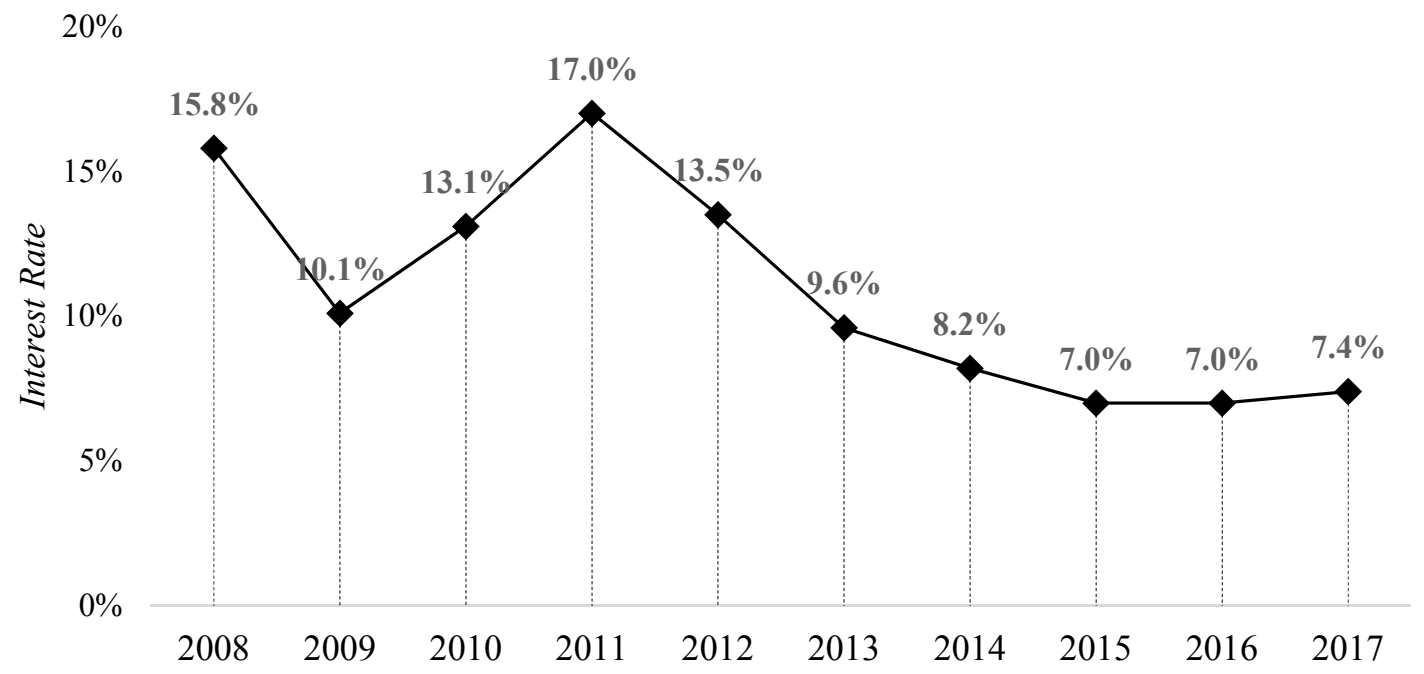

Figure 1. Lending Interest Rate of Vietnam 2008-2017. Source: World Bank.

\section{Concluding Remarks}

Financing decision is always important for any firm. As such, an appropriate model for firms to follow in making their financing decisions is desired. Unfortunately, mixed evidence has been emerged in previous empirical studies. In addition, limited number of studies addressed this important question in the context of Vietnam. As such, this study is conducted to examine an appropriate model in which the Vietnamese firms employ to determine their capital structures. In addition, the study also measures the impact of different factors on capital structure decisions of the Vietnamese listed firms.

The study develops four models based on studies of Shyam-Sunder and Myers (1999), Frank and Goyal (2003), Yu and Aquino (2009), and Razak and Rosli (2014). The pecking order theory is tested by two models including the original pecking order model and the partially aggregated pecking order model. In addition, the trade-off theory is tested using the target adjustment model. The study also utilizes the effect of factors on leverage model to measure the impact of different factors on capital structure decisions of Vietnamese listed firms. Unlike many other studies, a panel dataset of 227 HOSE listed firms over the period 2008 to 2017 and Generalized Method of Moment (GMM) approach are used. The use of GMM and panel data analysis help to effectively control unobservable firm-specific fixed effects but are very critical in capital structure decisions of firms.

The study finds no evidence that the pecking order theory can explain financing decisions of Vietnamese listed firms over the period 2008 to 2017. On the contrary, the empirical results strongly support that Vietnamese listed firms have followed the trade-off theory to determine their capital structures. The empirical results from the effect of factors on leverage model also suggest fund flow deficit has a negative impact on the amount of debt issued which is consistent with the result from the pecking order model, and change in sales has a positive influence on the amount of debt issued.

On the grounds of the findings from this paper, implications are drawn for academics, investors and firms, and also the Vietnamese government.

First, for academics, the study provides additional empirical evidence to answer one of the most arguable topics in the corporate finance in relation to how firms determine their capital structure. This paper provides empirical evidence that listed firms in Vietnam do not follow the pecking order theory. They have followed the trade-off theory to determine their optimal capital structure. The study also contributes to the capital structure study in Vietnam where the finance literature has not been thoroughly investigated. However, for robustness, studies in the future should consider the potential limitation of this paper as discussed further below.

Second, Vietnamese firms may consider the findings from this paper as a reference and a starting point to choose an appropriate capital structure in order to maximize firm's value. Vietnamese firms appear to have a tendency to substitute between debt and equity to move towards the target debt ratio. 
Third, for the Vietnamese government, Vietnamese firms depend heavily on debt to finance their capital structure and Vietnam's financial markets have not yet developed with a variety of choices. According to the NFSC (the National Finance Supervisory Commission) report, the banking system is the main capital supply source for the economy accounting over 60 percent of total supply. Depending heavily on banking loans brings risks to firms in relation to meet their obligations to pay interest expenses and debt repayment, in particular when lending interest rate increases. As a result, the Vietnamese government should put more effort to improve the financial market in terms of products and choices.

This study exhibits some limitations. For example, an extended period is desirable to consider a potential difference between various periods, in particular crisis and normal periods. Advanced techniques on risk measurements can also be considered and utilized such as credit risk measurements (Powell et al. 2017, 2018). In addition, this study only focuses on the Ho Chi Minh City stock market which may not be the complete proxy for the Vietnamese listed firms. The sample should be extended to include firms listed in Ha Noi stock market as well. It is because the ruling of listings between these two markets is significantly different. Last but not least, in addition to testing the appropriateness and validity of the three typical models, the characteristics of firms included in the study should be carefully considered as the difference in firms' characteristics is expected to influence firms' financing decisions.

Author Contributions: H.H.N.: Methodology, Data curation, Formal analysis, Software, Writing—original draft. C.M.H.: Writing—review \& editing, Analysis, Resources, Validation. D.H.V.: Conceptualization, Writing一original draft, Writing-review \& editing, Validation, Supervision.

Funding: This research received no external funding.

Acknowledgments: We are grateful to the three anonymous referees for their constructive comments. We also thank the participants at the 3rd Vietnam's Business and Economics Research Conference VBER2019 (Ho Chi Minh City Open University, Vietnam, 18-20 July 2019) for their helpful suggestions. The authors wish to acknowledge financial supports from Ho Chi Minh City Open University. The authors are solely responsible for any remaining errors or shortcomings.

Conflicts of Interest: The authors declare no conflict of interest.

\section{References}

Agha, Jahanzeb, Saif-Ur-Rehman Khan, Norkhairul Hafiz Bajuri, Meisam Karami, and Aiyoub Ahmadimousaabad. 2013. Trade-off theory, pecking order theory and market timing theory: A comprehensive review of capital structure theories. International Journal of Management and Commerce Innovations 1: 11-18.

Atiyet, Ben Amor. 2012. The Pecking Order Theory and the Static Trade off Theory: Comparison of the Alternative Explanatory Power in French Firms. Journal of Business Studies Quarterly 4: 1-14.

Balios, Dimitris, Nikolaos Daskalakis, Nikolaos Eriotis, and Dimitrios Vasiliou. 2016. SMEs capital structure determinants during severe economic crisis: The case of Greece. Cogent Economics \& Finance 4: 1-12.

Berger, Philip, Eli Ofek, and David Yermack. 1997. Managerial entrenchment and capital structure decisions. The Journal of Finance 52: 1411-38. [CrossRef]

Chirinko, Robert, and Anuja Singha. 2000. Testing static tradeoff against pecking order models of capital structure: A critical comment. Journal of Financial Economics 58: 417-25. [CrossRef]

Coles, Jeffrey L., and Zhichuan Frank Li. 2018. Managerial attributes, incentives, and performance. SSRN. [CrossRef]

Flannery, Mark, and Kasturi Rangan. 2006. Partial adjustment toward target capital structures. Journal of Financial Economics 79: 469-506. [CrossRef]

Frank, Murray, and Vidhan Goyal. 2003. Testing the pecking order theory of capital structure. Journal of Financial Economics 67: 217-48. [CrossRef]

Friend, Irwin, and Larry Lang. 1988. An empirical test of the impact of managerial self-interest on corporate capital structure. The Journal of Finance 43: 271-81. [CrossRef]

Giroud, Xavier, and Holger Mueller. 2010. Does corporate governance matter in competitive industries? Journal of Financial Economics 95: 312-31. [CrossRef] 
Giroud, Xavier, and Holger Mueller. 2011. Corporate governance, product market competition, and equity prices. The Journal of Finance 66: 563-600. [CrossRef]

Kannadhasan, M., Bhanu Thakur, C. Gupta, and Parikshit Charan. 2018. Testing capital structure theories using error correction models: Evidence from China, India, and South Africa. Cogent Economics E Finance 6: 1443369

Kopecky, Kenneth, Zhichuan Li, Timothy Sugrue, and Alan Tucker. 2018. Revisiting M\&M with Taxes: An Alternative Equilibrating Process. International Journal of Financial Studies 6: 10.

Maças Nunes, Paulo, and Zélia Serrasqueiro. 2017. Short-term debt and long-term debt determinants in small and medium-sized hospitality firms. Tourism Economics 23: 543-60. [CrossRef]

Miller, Edward. 1977. Risk, Uncertainty, and Divergence of Opinion. The Journal of Finance 32: 1151-68. [CrossRef]

Modigliani, Franco, and Merton Miller. 1958. The cost of capital, corporation finance and the theory of investment. American Economic Review 48: 261-97.

Morellec, Erwan, Boris Nikolov, and Norman Schürhoff. 2012. Corporate governance and capital structure dynamics. The Journal of Finance 67: 803-48. [CrossRef]

Nunkoo, Pravish, and Agyenim Boateng. 2010. The empirical determinants of target capital structure and adjustment to long-run target: Evidence from Canadian firms. Applied Economics Letters 17: 983-90. [CrossRef]

Pacheco, Luís. 2016. Capital structure and internationalization: The case of Portuguese industrial SMEs. Research in International Business and Finance 38: 531-45. [CrossRef]

Powell, Robert, Duc H. Vo, and Thach N. Pham. 2017. The long and short commodity tails and their relationship to Asian equity markets. Journal of Asian Economics 52: 32-44. [CrossRef]

Powell, Robert, Duc H. Vo, and Thach N. Pham. 2018. Economic cycles and downside commodities risk. Applied Economics Letter 25: 258-63. [CrossRef]

Razak, Nazrul, and Mohd Rosli. 2014. A test between Pecking Order Hypothesis and Static Trade-Off Theory: An Analysis from Malaysian Listed Firms for Periods of Year 2007 To 2012. International Journal of Business and Commerce 3: 99-117.

Sheikh, Jibran, Wajid Ahmed, and Muhammad Masood. 2012. Pecking at pecking order theory: Evidence from Pakistan's non-financial sector. Journal of Competitiveness 4: 86-95. [CrossRef]

Shyam-Sunder, Lakshmi, and Stewart Myers. 1999. Testing static tradeoff against pecking order models of capital structure. Journal of Financial Economics 51: 219-44. [CrossRef]

Tran, Minh, and Duc Vo. 2015. The appropriateness of the pecking order theory in corporate capital structure in Vietnam. Banking Technology Review 106-107: 25-42.

Trinh, Huong, Makoto Kakinaka, Donghun Kim, and Tae Yong Jung. 2017. Capital structure and investment financing of small and medium-sized enterprises in Vietnam. Global Economic Review 46: 325-49. [CrossRef]

Vijayakumar, Ashvin. 2011. An empirical investigation of the trade-off and pecking order hypotheses on Indian automobile firms. International Journal of Research in Commerce, Economics E Management 1: 94-100.

Vo, Duc, and Van Nguyen. 2014. Managerial ownership, leverage and dividend policies: Empirical evidence from Vietnam's listed firms. International Journal of Economics and Finance 6: 274-99. [CrossRef]

Wen, Yu, Kami Rwegasira, and Jan Bilderbeek. 2002. Corporate governance and capital structure decisions of the Chinese listed firms. Corporate Governance: An International Review 10: 75-83. [CrossRef]

Yu, Darwin, and Rodolfo Aquino. 2009. Testing capital structure models on Philippines listed firms. Applied Economics 41: 1973-90. [CrossRef]

(C) 2019 by the authors. Licensee MDPI, Basel, Switzerland. This article is an open access article distributed under the terms and conditions of the Creative Commons Attribution (CC BY) license (http://creativecommons.org/licenses/by/4.0/). 